\title{
ПОРІВНЯЛЬНА ХАРАКТЕРИСТИКА М'ЯСНИХ ТА ЗАБІЙНИХ ЯКОСТЕЙ КАЧОК ПРИ ВИРОЩУВАННІ НА ТЕРИТОРІЇ РАДІОАКТИВНОГО ЗАБРУДНЕННЯ
}

\author{
Ковальова Світлана Петрівна \\ кандидат сільськогосподарських наук, ст. викладач \\ Житомирська філія ДУ «Держгрунтохорона» \\ ORCID: 0000-0003-1858-625X \\ Email: kovalev_zt@ukr.net
}

Ільніцька Олена Володимирівна завідувач лабораторії експериментальних досліджень, геоінформаційних систем та обробки інформації Житомирська філія ДУ «Держгрунтохорона» Email: soils1964@ukr.net

Гавриловський Володимир Петрович викладач, заступник директора з навчально-виробничої роботи

Житомирський агротехнічний коледж Email: verba5551@ukr.net

Вербельчук Сергій Петрович кандидат сільськогосподарських наук, доцент Поліський національний університет ORCID: 0000-0002-1136-5617 Email: verba5551@ukr.net

Кобернюк Віра Василівна кандидат сільськогосподарських наук, доцент Поліський національний університет ORCID: 0000-0001-7037-8269 Email: kobernukvera@gmail.com

Вербельчук Тетяна Василівна кандидат сільськогосподарських наук, доцент Поліський національний університет ORCID: 0000-0001-7334-4507 Email: ver-ba555@ukr.net

\begin{abstract}
У статті представлені результати досліджень м'ясних та забійних якостей качок за різних способів утримання при вирощуванні в підсобних господарствах 2-ої зони радіоактивного забруднення. Теоретично і практично обгрунтовано екологічну безпечність виробництва качиного м'яса за безвигульного та вигульного утримання, як одного із основних продуктів харчування населення, що проживає у регіонах, які зазнали радіоактивного забруднення внаслідок аварії на ЧAEC. Науково-господарські дослідження з вирощування качок на радіоактивно забруднених територіях проводились у 2011-2012 рр. в селі Христинівка Народицького району Житомирської області. Щільність забруднення території цезієм137 становила >15 Ki/км². Для дослідів за принципом пар-аналогів було відібрано 60 голів качок із середньою живою масою 40,6 г кожна (при безвигульному утриманні), з 30-ти денного віку качки були розділені на дві групи залежно від способу утримання - вигульний та безвигульний, по 25 голів у кожній, середня жива маса каченят - 520 г. Піддослідна птиия безвигульного способу утримання знаходилася упродовж дня у загороджі з навісом від дощу та сония, а на ніч качки переганяли у закрите приміщення. Піддослідні качки (вигульний спосіб утримання) впродовж дня перебували з природним обмеженням на території водоймища 0,4-0,6 га. Для годівлі качок цієї групи заганяли у клітку, а для ночівлі - у приміщення. Обмежені водоймища були бідні природною кормовою базою, тому потребу каченят у поживних речовинах повністю забезпечували за рахунок раціонів. Результатами досліджень доведено, що способи утримання качок впливають на ріст і розвиток птиці, масу патраних тушок, вихід складових частин тушки та накопичення ${ }^{137} \mathrm{Cs}$ у м'ясі птиці. Качки вигульного способу утримання характеризувалися більшою живою масою, кращим розвитком внутрішніх органів, масою патраних тушок, виходом м'язів. Дослідженнями встановлено, що питома активність ${ }^{137} \mathrm{Cs}$ у м'ясі піддослідних качок обох груп не перевищувала допустимі рівні і варіювала у межах 12,9-75,9 Бк/ка. Питома активність ${ }^{137} \mathrm{Cs}$ у м'язах качок вигульного способу утримання була на 21-46 \% меншою у порівнянні із м'ясом птиці безвигульного способу утримання. Обгрунтовано екологічну безпечність виробництва качиного м'яса для жителів 2-ої зони радіоактивного забруднення, як за безвигульного, так і вигульного способу утримання, надаючи перевагу останньому.
\end{abstract}

Вісник Сумського національного аграрного університету 
Ключові слова: качки, вигульний та безвигульний способи утримання, радіоактивно забруднена територія, питома активність, ріст та розвиток, патрана тушка, передзабійна маса.

DOI: https://doi.org/10.32845/bsnau.lvst.2021.1.7

Постановка проблеми. Одним із найважливіших наслідків Чорнобильської аварії стало радіоактивне забруднення сільськогосподарських угідь та природних та напівприродних екосистем, що створило тривалу небезпеку потрапляння радіонуклідів в організм людини [1, 6, 12].

Встановлено, що у віддалений період після аварії на Чорнобильській AEC радіологічна ситуація для сільського населення Полісся покращилася, але все ще існують критичні райони, що становлять радіаційну небезпеку для сільського населення $[1,13,16]$.

Наслідки аварії були особливо важкими для населення Житомирського Поліського регіону - північної частини Волинської, Житомирської, Київської, Рівненської та Чернігівської областей, який найбільше постраждав від радіоактивного забруднення в результаті аварії [15]. У цій зоні сільське господарство було основним видом життєдіяльності, так як природні ландшафрти (луки, пасовища, ліс) були найважливішою ланкою виробництва $[5,10,24]$.

Суттєвого радіоактивного забруднення зазнала майже половина території Житомирської області. Переважає тут Народицький і Овруцький район, значна частина Лугинського і Коростенського районів. В інших районах щільність забруднення залишається набагато нижчою $[2,7]$.

Після аварії на Чорнобильській АЕС в Україні, в тому числі в Житомирській області, площа ріллі, сіножатей, посівів, картоплі та кормових культур різко впала [23]. Така ситуація позначилася на скороченні поголів'я великої рогатої худоби, виробництві основних продуктів тваринництва м'яса, молока яєць, котрі мали високий рівень забруднення радіонуклідами, що в подальшому визначило рівні опромінення проживаючого населення $[9,14]$. Тут почали вирощувати кіз та птицю (кури, гуси, качки), використовуючи екологічно чисте м'ясо для збагачення раціону та зменшення впливу дози внутрішнього опромінення людини [8].

Радіонукліди являють велику небезпеку для живих організмів $[3,20,21,22]$. Тому сільськогосподарське виробництво на сучасному етапі та в створених умовах, повинно використовувати технології, що допоможуть мінімізувати міграцію шкідливих речовин у харчовому ланцюзі: «'рунт рослина (корми) - тварина (птиця) - сільськогосподарська продукція - людина (продукти харчування)», виключаючи можливість збільшення зони забруднення радіонуклідами, забезпечувати радіаційний захист населення, що живе і працює в цих регіонах $[4,16]$.

На території Житомирської області у зоні безумовного (обов'язкового) відселення продовжують проживати люди та вести господарство $[11,18]$. Тому, залишається актуальним визначення ризиків для здоров'я людей, вивчення впливу радіоактивного забруднення на навколишнє середовище, прогнозування стратегічних напрямів вирішення проблем розповсюдження радіонуклідів у воді, повітрі, грунті, сільськогосподарській продукції, вивчення можливих наслідків цих явищ для конкретних груп населення, які піддаються ризику, враховуючи їх спосіб життя $[4,8,19]$.

3 давніх-давен водоплавні птахи в Україні, як і інші сільськогосподарські птахи, займали особливе місце в господарствах селян [2]. Порівняно низька вартість кормів та робочої сили для вирощування цих птахів дозволяє отрима- ти цінне м'ясо, пір'я, сировину для домашнього використання та продажу на ринку [17].

Основними перевагами при розведенні качок $€$ їх біологічні особливості: енергія росту в молодому віці, хороше використання дешевих кормів, невибагливість і висока плодючість [2]. Качки здатні виробляти продукцію у звичайних умовах, тому у багатьох країнах у харчуванні вона $є$ головним джерелом натурального протеїну. М'ясо качки містить більше 20 \% білку та є продуктом із оптимальними співвідношеннями амінокислотного складу. Качине м'ясо має специфічний смак, воно ніжне, соковите і біологічно повноцінне. При цьому качок вирощують для отримання м'яса, яєць, жирної печінки та пір'я [7].

У зв'язку з цим в контексті сучасного техногенного забруднення, екологічні проблеми, пов'язані з покращенням якості продукції тваринництва та їх харчової безпеки, стають все більш важливими.

Метою досліджень було проведення порівняльної характеристики м'ясних та забійних якостей качок за різних способів утримання при вирощуванні в умовах підсобного господарства на території радіоактивного забруднення.

Основним завданням досліджень було дослідити ріст та розвиток качок, вихід основних частин тушки, накопичення ${ }^{137}$ Cs у м'ясі качок при вирощуванні за різних способів утримання.

Матеріали та методи досліджень. Дослідження проведені у період 2001 та у 2012 року у населеному пункті Христинівка Народицького району, де щільність забруднення ірунтів ${ }^{137} \mathrm{Cs}$ становила більше 555 кБк/м².

Досліди проведено безпосередньо у виробничих умовах приватних господарств. Для проведення дослідів на районних інкубаторних станціях закуповувалися однодобові каченята пекінської породної групи. Всього було закуплено по 60 голів однодобових каченят, котрі мали середню живу масу у $2001-39,9$ г, у 2012 p - 40,6 г. Для дослідів групи каченят у 30-ти денному віці сфрормували у дві групи по 25 голів кожна за принципом аналогів, з врахуванням віку, статті живої маси, походження, клінічного стану здоров'я. Середня жива маса піддослідних каченят за роками становила 525 г і 520 г у 2001 та у 2012 роках, відповідно [8].

Перший місяць досліджень (30 днів), який був зрівняльним періодом, всіх каченят утримували у клітках із забезпеченням кормів та води

Всі піддослідні качки (50 голів) окільцьовували та зважували індивідуально.

Піддослідна птиця безвигульного способу утримання знаходилася упродовж дня у загорожі, яка завдяки навісу захищала від несприятливих погодних умов, ночували качки у закритому приміщенні.

Інші піддослідні качки (вигульний спосіб утримання) знаходилися щоденно на території біля водоймища, площею 0,4-0,6 га, з природним обмеженням. Годівля качок проводилися у клітках, ночівля у приміщеннях закритого типу. Поживними речовинами качки забезпечувалися завдяки збалансованим раціонам годівлі, так як обмежені водоймища були бідні на природну кормову базу.

Годівля піддослідної птиці обох груп була однаковою, здійснювалася на основі деталізованих норм, які повністю 
задовольняли їх потребу в поживних речовинах. До складу раціонів входили місцеві корми.

Дослідження якісних показників корму та органів проводили лабораторії відділу тваринництва Інституту сільського господарства Полісся НААН України відповідно чинної нормативної документації $[7,8]$.

Біометричну обробку експериментальних досліджень проводили на ПК за допомогою програмного забезпечення Micrsoft Offise Excel. Результати вважали достовірними при $\left.\mathrm{P} \geq 0,95\left(^{*}\right), \mathrm{P} \geq 0,99\left(^{* *}\right), \mathrm{P} \geq 0,999{ }^{* * *}\right)$.

Результати досліджень. Результати досліджень показали, що краще розвивалася птиця обох дослідів за вигульного способу утримання. Так, качки вигульного утримання у віці 60 днів мали більшу живу масу на 4,0 та 2,5\%, у 90 днів - на 4,7 і 4,6 \%, у 120 днів - на 4,8 та 4,9\% та у 150денному віці - на 3,5 і 3,3 \% у порівнянні із живою масою качок безвигульного способу утримання відповідно по роках досліджень (табл. 1).

Жива маса качок при безвигульному способі утримання у порівнянні із масою птиці при постановці на дослід у 2001 році збільшилась у 2-місячному віці - у 2,5 рази, у 3-місячному віці - у 3,8, у 4-х місячному віці - у 4,4 і у 5-ти місячному - у 4,7 разів. При вигульному способі утримання жива маса качок збільшилася відповідно у 2,6; 3,9; 4,6 та 4,9 рази.

Таблиця 1

\begin{tabular}{|c|c|c|c|c|c|c|}
\hline \multirow{3}{*}{ Спосіб утримання птиці } & \multirow{3}{*}{$\begin{array}{l}\text { Одиниці } \\
\text { виміру }\end{array}$} & Інамıка жив & аси качок зе & од вирощув &, $\mathrm{M} \pm \mathrm{m}$ & \\
\hline & & \multicolumn{5}{|c|}{ Вік птиці, днів } \\
\hline & & $0-30^{*}$ & $31-60$ & $61-90$ & $91-120$ & $121-150$ \\
\hline \multicolumn{7}{|c|}{2001 рік } \\
\hline \multirow{2}{*}{ Безвигульний } & $\Gamma$ & $509,6 \pm 17,5$ & $1285,0 \pm 29,4$ & $1914,8 \pm 38,6$ & $2253,3 \pm 43,8$ & $2410,8 \pm 54,2$ \\
\hline & $\%$ & $x$ & 100 & 100 & 100 & 100 \\
\hline \multirow{2}{*}{ Вигульний } & $\Gamma$ & $510,2 \pm 16,3$ & $1336,5 \pm 27,9$ & $2005,4 \pm 35,8$ & $2360,6 \pm 46,9$ & $2495,0 \pm 56,5$ \\
\hline & $\%$ & $x$ & 104,0 & 104,7 & 104,8 & 103,5 \\
\hline \multicolumn{7}{|c|}{2012 рік } \\
\hline \multirow{2}{*}{ Безвигульний } & г & $525,2 \pm 18,9$ & $1366,1 \pm 28,3$ & $1983,4 \pm 37,2$ & $2304,8 \pm 44,7$ & $2488,6 \pm 60,1$ \\
\hline & $\%$ & $x$ & 100 & 100 & 100 & 100 \\
\hline \multirow{2}{*}{ Вигульний } & r & $526,6 \pm 17,4$ & $1400,0 \pm 26,7$ & $2075,4 \pm 35,9$ & $2418,5 \pm 39,6$ & $2570,3 \pm 54,2$ \\
\hline & $\%$ & $x$ & 102,5 & 104,6 & 104,9 & 103,3 \\
\hline
\end{tabular}

Середньодобовий приріст живої маси качок вигульного утримання у дослідженнях 2001 та 2012 років у період 3 31 до 120 днів був більшим проти аналогічних показників

Таблиця 2

Середньодобовий приріст живої маси качок

\begin{tabular}{|c|c|c|c|c|c|c|}
\hline \multirow{2}{*}{ Спосіб утримання птиці } & \multirow{2}{*}{ Одиниці виміру } & \multicolumn{5}{|c|}{ Вік птиці, днів } \\
\hline & & $0-30$ & $31-60$ & $61-90$ & $91-120$ & $121-150$ \\
\hline \multicolumn{7}{|c|}{2001 рік } \\
\hline \multirow{2}{*}{ Безвигульний } & $\Gamma$ & 15,7 & 25,9 & 21,0 & 11,3 & 5,3 \\
\hline & $\%$ & 100 & 100 & 100 & 100 & 100 \\
\hline \multirow{2}{*}{ Вигульний } & 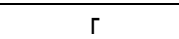 & 15,7 & 27,6 & 22,3 & 11,8 & 4,5 \\
\hline & $\%$ & 100 & 106,6 & 106,2 & 104,4 & 84,9 \\
\hline \multicolumn{7}{|c|}{2012 рік } \\
\hline \multirow{2}{*}{ Безвигульний } & $\Gamma$ & 16,1 & 28,0 & 20,6 & 10,7 & 6,1 \\
\hline & $\%$ & 100 & 100 & 100 & 100 & 100 \\
\hline \multirow{2}{*}{ Вигульний } & $\Gamma$ & 16,1 & 29,2 & 22,5 & 11,4 & 5,1 \\
\hline & $\%$ & 100 & 104,3 & 109,2 & 106,5 & 83,6 \\
\hline
\end{tabular}

Проте, в останній місяць вирощування качок середньодобові прирости птиці вигульного способу утримання зменшилися на $15,1 \%$ та 16,4 \%, відповідно по роках проведення досліджень, що пов'язано із початком яйцекладки у качок цієї групи.

Аналогічна закономірність встановлена між групами у розвитку внутрішніх органів.

Так, у 2001 році при вирощуванні птиці за вигульного способу утримання середня маса серця, печінки, м'язового шлунку, легенів і нирок за 150 днів вирощування була на $9,1 \%, 10,3 \%, 6,6 \%, 6,3$ \% і на 5,8 \% відповідно більша маси внутрішніх органів качок безвигульного утримання. Така ж закономірність розвитку внутрішніх органів збереглася і при дослідженнях у 2012 році. Качки вигульного способу утримання по масі серця, печінки, м'язового шлунку, легенів та нирок у п'ятимісячному віці переважали на 7,8 \%, 4,5 \%, 4,9 $\%, 5,0 \%$ та 7,3 \% масу цих органів качок безвигульного способу утримання (табл. 3). птиці безвигульного способу утримання на 6,6 та 4,3 \%; 6,2 та 9,2 \%; 4,4 та 6,5 \% відповідно (табл. 2).

Відносна маса внутрішніх органів качок за вигульного утримання також виявилася більшою у порівнянні із органами птиці безвигульного утримання (табл. 4). У 2-х, 4-х і 5-ти місячному віці показники відносної маси внутрішніх органів у качок вигульного способу утримання переважали масу птиці безвигульного утримання.

Отримані результати досліджень підтвердили те, що внутрішні органи качок розвиваються на ранніх стадіях вирощування. Так, у дослідженнях 2001 та 2012 років незалежно від способу утримання, внутрішні органи переважно розвивались у період до 4-х місяців. У цей період маса серця збільшилася у 1,77-2,05 рази, маса печінки - у 1,41,6 рази, маса м'язевого шлунку - у 1,1-1,27 рази, маса легенів - у 1,4 рази, маса нирок - у 1,5 рази.

Для характеристики забійних якостей піддослідної птиці визначали масу складових частин тушок у 2-х місячному та 5-ти місячному віці. 
Таблиця 3

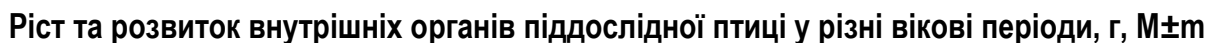

\begin{tabular}{|c|c|c|c|c|c|}
\hline \multirow{4}{*}{ Вік птиці, днів } & \multirow{4}{*}{ Показник } & \multicolumn{4}{|c|}{ Досліди } \\
\hline & & 2001 рік & 2012 рік & 2001 рік & 2012 рік \\
\hline & & \multicolumn{4}{|c|}{ Спосіб утримання } \\
\hline & & \multicolumn{2}{|c|}{ безвигульний } & \multicolumn{2}{|c|}{ вигульний } \\
\hline \multirow{6}{*}{60} & Передзабійна вага & 1250,0 & 1356,0 & 1330,0 & 1375,0 \\
\hline & Серце & $9,4 \pm 0,40$ & $10,5 \pm 0,26$ & $10,6 \pm 0,62$ & $10,8 \pm 0,36$ \\
\hline & Печінка & $43,0 \pm 2,0$ & $47,1 \pm 2,15$ & $47,3 \pm 1,88$ & $48,0 \pm 2,66$ \\
\hline & М'язевий шлунок & $65,0 \pm 3,15$ & $71,0 \pm 4,10$ & $70,0 \pm 4,20$ & $71,9 \pm 3,88$ \\
\hline & Легені & $13,3 \pm 0,3$ & $14,8 \pm 0,62$ & $14,4 \pm 0,40$ & $15,4 \pm 0,60$ \\
\hline & Нирки & $11,3 \pm 0,44$ & $12,4 \pm 0,52$ & $12,2 \pm 0,38$ & $13,0 \pm 0,56$ \\
\hline \multirow{6}{*}{120} & Передзабійна вага & 2229,3 & 2300,0 & 2352,3 & 2396,6 \\
\hline & Серце & $18,0 \pm 0,6$ & $18,9 \pm 0,50$ & $19,9 \pm 0,70$ & $20,1 \pm 0,70$ \\
\hline & Печінка & $62,5 \pm 1,65$ & $65,3 \pm 1,55$ & $68, \pm 2,56$ & $69,3 \pm 2,22$ \\
\hline & М'язевий шлунок & $82,8 \pm 3,49$ & $85,0 \pm 3,74$ & $87,7 \pm 2,88$ & $89,5 \pm 3,24$ \\
\hline & Легені & $18,8 \pm 0,74$ & $19,6 \pm 0,70$ & $20,0 \pm 0,80$ & $20,6 \pm 0,80$ \\
\hline & Нирки & $17,0 \pm 0,68$ & $17,4 \pm 0,60$ & $18,1 \pm 0,58$ & $18,0 \pm 0,46$ \\
\hline \multirow{6}{*}{150} & Передзабійна вага & 2400,0 & 2456,3 & 2500,0 & 2551,6 \\
\hline & Серце & $18,6 \pm 0,54$ & $19,2 \pm 0,63$ & $20,3 \pm 0,48$ & $20,7 \pm 0,44$ \\
\hline & Печінка & $63,0 \pm 1,55$ & $66,8 \pm 1,75$ & $69,5 \pm 3,0$ & $69,8 \pm 3,56$ \\
\hline & М'язевий шлунок & $83,2 \pm 3,0$ & $86,3 \pm 2,86$ & $88,7 \pm 3,10$ & $90,5 \pm 2,84$ \\
\hline & Легені & $19,1 \pm 0,72$ & $19,9 \pm 0,84$ & $20,3 \pm 0,90$ & $20,9 \pm 0,72$ \\
\hline & Нирки & $17,2 \pm 0,60$ & $17,7 \pm 0,80$ & $18,2 \pm 0,74$ & $19,0 \pm 0,65$ \\
\hline
\end{tabular}

Вікові зміни відносної маси внутрішніх органів у піддослідних качок

Таблиця 4

\begin{tabular}{|c|c|c|c|c|c|}
\hline \multirow{4}{*}{ Вік птиці, днів } & \multirow[b]{5}{*}{ ПЛпепзабійна } & \multicolumn{4}{|c|}{ Досліди } \\
\hline & & 2001 pik & 2012 рік & $2001 \mathrm{piк}$ & 2012 рік \\
\hline & & \multicolumn{4}{|c|}{ Способи утримання } \\
\hline & & \multicolumn{2}{|c|}{ безвигульний } & \multicolumn{2}{|c|}{ вигульний } \\
\hline \multirow{6}{*}{60} & & 1250,0 & 1356,0 & 1330,0 & 1375,0 \\
\hline & Серце, \% & 0,75 & 0,77 & 0,79 & 0,80 \\
\hline & Печінка, \% & 3,44 & 3,47 & 3,49 & 3,56 \\
\hline & М'язевий шлунок, \% & 5,20 & 5,24 & 5,23 & 5,26 \\
\hline & Легені, \% & 1,06 & 1,09 & 1,08 & 1,12 \\
\hline & Нирки, \% & 0,90 & 0,91 & 0,92 & 0,94 \\
\hline \multirow{6}{*}{120} & Передзабійна вага, г & 2229,3 & 2300,0 & 2352,3 & 2396,6 \\
\hline & Серце, \% & 0,81 & 0,82 & 0,84 & 0,85 \\
\hline & Печінка, \% & 2,80 & 2,84 & 2,89 & 2,91 \\
\hline & М'язевий шлунок, \% & 3,71 & 3,70 & 3,73 & 3,73 \\
\hline & Легені, \% & 0,84 & 0,85 & 0,85 & 0,86 \\
\hline & Нирки, \% & 0,76 & 0,76 & 0,77 & 0,78 \\
\hline \multirow{6}{*}{150} & Передзабійна вага, г & 2400,0 & 2456,3 & 2500,0 & 2551,6 \\
\hline & Серце, \% & 0,78 & 0,78 & 0,81 & 0,81 \\
\hline & Печінка, \% & 2,63 & 2,72 & 2,74 & 2,78 \\
\hline & М'язевий шлунок, \% & 3,47 & 3,51 & 3,55 & 3,55 \\
\hline & Легені, \% & 0,80 & 0,81 & 0,81 & 0,82 \\
\hline & Нирки, \% & 0,72 & 0,72 & 0,73 & 0,74 \\
\hline
\end{tabular}

Дослідженнями встановлено переваги передзабійної маси качок вигульного способу утримання по відношенню до їх аналогів за безвигульного способу утримання. Передзабійна маса була вищою на 3,9 \% у 60-ти денному і на 2,6 \% - у 150-ти денному віці. Аналогічна тенденція по збільшенню передзабійної маси качок мала місце і у дослідженнях 2012 року, де забійна маса качок вигульного утримання виявилася на 2,5 \% у 60-ти денному і на 2,9 \% у 150-ти денному віці вищою аналогічного показника птиці безвигульного утримання (табл. 5).

Така ж закономірність збереглася між групами по масі патраних тушок. У дослідженнях 2001 та 2012 років маса патраних тушок птиці вигульного способу утримання була на 4,6 і 3,8 \% у 60-ти денному та на 4,0 і 4,3 \% у 150-ти денному віці вищою у порівнянні з цим показником птиці безвигульного способу утримання.

Вихід патраних тушок качок по відношенню до передзабійної маси птиці у двохмісячному віці становив 57,2 і $59,5 \%$ у качок безвигульного способу утримання та 57,6 і 60,3 \% у птиці вигульного способу. У п'ятимісячному віці у качок безвигульного способу утримання цей показник становив 59,3 і 60,4 \% та 60,1 і 61,2 \% у птиці вигульного утримання відповідно по роках проведення досліджень. 
Таблиця 5

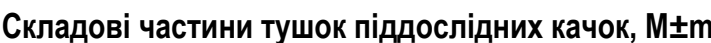

\begin{tabular}{|c|c|c|c|c|}
\hline \multirow{4}{*}{ Показники } & \multicolumn{4}{|c|}{ Способи утримання } \\
\hline & \multicolumn{2}{|c|}{ безвигульний } & \multicolumn{2}{|c|}{ вигульний } \\
\hline & \multicolumn{4}{|c|}{ Вік птиці, дні } \\
\hline & 60 & 150 & 60 & 150 \\
\hline \multicolumn{5}{|c|}{2001 рік } \\
\hline Передзабійна маса, г & $1300,0 \pm 43,2$ & $2485,6 \pm 77,8$ & $1350,3 \pm 56,0$ & $2550,0 \pm 72,6$ \\
\hline Маса патраної тушки, г & $743,6 \pm 20,6$ & $1474,0 \pm 53,0$ & $777,8 \pm 22,4$ & $1532,6 \pm 47,2$ \\
\hline$\%$ & 57,2 & 59,3 & 57,6 & 60,1 \\
\hline \multicolumn{5}{|c|}{ Маса складових частин тушки до передзабійної маси: } \\
\hline м'язи, г & $344,5 \pm 12,2$ & $703,4 \pm 22,6$ & $361,9 \pm 10,1$ & $739,5 \pm 24,5$ \\
\hline$\%$ & 26,5 & 28,3 & 26,8 & 29,0 \\
\hline шкіра, г & $213,2 \pm 9,1$ & $421,6 \pm 16,0$ & $222,8 \pm 8,6$ & $423,3 \pm 17,3$ \\
\hline$\%$ & 16,4 & 16,6 & 16,5 & 16,6 \\
\hline кістки, г & $185,9 \pm 7,6$ & $357,9 \pm 14,4$ & $193,0 \pm 8,2$ & $369,8 \pm 11,6$ \\
\hline$\%$ & 14,3 & 14,4 & 14,3 & 14,5 \\
\hline \multicolumn{5}{|c|}{2012 рік } \\
\hline Передзабійна маса, г & $1405,4 \pm 51,4$ & $2562,8 \pm 75,8$ & $1440,0 \pm 66,0$ & $2637,4 \pm 82,2$ \\
\hline Маса патраної тушки, г & $836,2 \pm 28,8$ & $1548,0 \pm 60,2$ & $868,3 \pm 32,4$ & $1614,1 \pm 57,1$ \\
\hline$\%$ & 59,5 & 60,4 & 60,3 & 61,2 \\
\hline \multicolumn{5}{|c|}{ Маса складових частин тушки до передзабійної маси: } \\
\hline м'язи, г & $392,1 \pm 16,4$ & $733,0 \pm 26,6$ & $409,0 \pm 12,2$ & $770,1 \pm 19,3$ \\
\hline$\%$ & 27,9 & 28,6 & 28,4 & 29,2 \\
\hline шкіра, г & $238,9 \pm 10,2$ & $438,2 \pm 18,2$ & $247,7 \pm 9,5$ & $453,6 \pm 15,4$ \\
\hline$\%$ & 17,0 & 17,1 & 17,2 & 17,2 \\
\hline кістки, г & $205,2 \pm 8,6$ & $376,7 \pm 16,8$ & $211,7 \pm 8,2$ & $390,3 \pm 11,6$ \\
\hline$\%$ & 14,6 & 14,7 & 14,7 & 14,8 \\
\hline
\end{tabular}

У той же час маса складових частин тушок качок по відношенню до передзабійної маси у обох дослідах не мала вірогідної різниці між групами. Маса м'язів, шкіри та кісток у качок безвигульного способу утримання у 60-ти денному віці була у межах 26,5 і 27,9 \%; 16,4 і 17,0\%; 14,3 i 14,6 \%, а у 150-ти денному віці - 28,3 і 28,6 \%; 16,6 і 17,1 \%; 14,4 і 14,7 \% відповідно у дослідженнях 2001 та 2012 років. У качок вигульного способу утримання ці показники були дещо вищими і становили 26,8 і 28,4 \%; 16,5 і 17,2 \%; 14,3 і 14,7 \% у двохмісячному віці, а у п'ятимісячному віці - 29,0 і 29,2 \%; 16,6 і 17,2 \%; 14,5 і 14,8 \% відповідно по роках досліджень. Однак, у дослідженнях 2012 року вихід м'язів у 60-ти денному віці качок був на 5,3 \% вищим у качок безвигульного утримання та на 6,0 \% у птиці вигульного утримання. У порівнянні з аналогічними показниками у 2001 році.

Відомо, що основна частина туші - це м'язова тканина. Якість м'яса залежить від її росту та розвитку.

При оцінці морфологічного складу тушок в порівнянні до патраної тушки встановлено, що вихід м'язів дещо пере- важав у качок вигульного способу та становив у 60-ти денному віці 46,5 та $46,9 \%$, а у 150 -ти денному - 48,3 та $47,7 \%$ відповідно по роках досліджень.

у качок безвигульного способу утримання вихід м'язів становив 46,3 і 46,9 \% та 47,7 \% відповідно по роках досліджень та періодах забою. Вихід кісток по відношенню до патраної тушки варіював у межах 24,1-25,0 \%, а вихід шкіри знаходився у межах від 27,6 \% до $28,7 \%$ і у обох дослідах був трохи нижчим у качок вигульного способу утримання.

Так, як дослідження по вирощуванню качок проводилися на території II зони радіоактивного забруднення, було проведено визначення питомої активності цезію-137 у м'язах піддослідної птиці.

Результатами досліджень встановлено, що м'ясо піддослідних качок по вмісту ${ }^{137} \mathrm{Cs}$ знаходилося значно нижче встановлених нормативів та доведена вірогідна різниця по накопиченню ${ }^{137} \mathrm{Cs}$ у м'язах качок між групами (табл. 6)

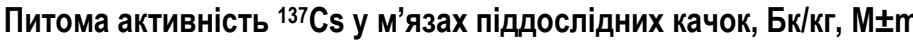

Таблиця 6

\begin{tabular}{|c|c|c|c|c|}
\hline \multirow{2}{*}{ № 3/ח } & \multirow{2}{*}{ Вік птиці, днів } & \multirow{2}{*}{ Рік проведення досліджень } & \multicolumn{2}{|c|}{ Спосіб утримання качок } \\
\hline & & & безвигульний & вигульний \\
\hline 1 & 30 & \multirow{5}{*}{2001} & $14,3 \pm 0,7$ & $14,3 \pm 0,7$ \\
\hline 2 & 60 & & $69,3 \pm 1,3$ & $54,0 \pm 2,1^{* \star}$ \\
\hline 3 & 90 & & $75,9 \pm 2,4$ & $45,3 \pm 1,8^{* \star}$ \\
\hline 4 & 120 & & $38,9 \pm 0,7$ & $25,5 \pm 0,8^{\star \star}$ \\
\hline 5 & 150 & & $30,0 \pm 1,2$ & $17,8 \pm 0,8^{* \star}$ \\
\hline 6 & 30 & \multirow{5}{*}{2012} & $12,9 \pm 0,8$ & $12,9 \pm 0,8$ \\
\hline 7 & 60 & & $56,6 \pm 2,0$ & $44,6 \pm 1,3^{* \star}$ \\
\hline 8 & 90 & & $60,0 \pm 1,3$ & $35,1 \pm 1,0^{\star \star}$ \\
\hline 9 & 120 & & $21,7 \pm 0,9$ & $14,8 \pm 0,6^{\star \star}$ \\
\hline 10 & 150 & & $20,8 \pm 0,8$ & $11,1 \pm 0,8^{\star \star}$ \\
\hline
\end{tabular}

* - різниці вірогідна, $p<0,05 ;{ }^{* *}$ - різниці вірогідна, $p<0,01$; *** - різниці вірогідна, $p<0,001$. 
При вирощуванні качок у обох дослідах за безвигульного способу утримання накопичення ${ }^{137} \mathrm{Cs}$ у м'язах качок відбувалося до 90-денного віку. Питома активність радіонукліду варіювала від 14,3 до 75,9 Бк/кг та від 12,9 до 60,0 Бк/кг відповідно у 2001 та 2012 роках. I лише після 3-х місячного віку спостерігалося зниження питомої активності ${ }^{137} \mathrm{Cs}$ cпочатку до 38,9 Бк/кг, а тоді до 30 Бк/кг (2001р.). У дослідженнях 2012 року зниження питомої активності ${ }^{137} \mathrm{Cs}$ спостерігалося до 21,7 Бк/кг у 4 місячному віці, а тоді до 20,8 Бк/кг.

У качок вигульного способу утримання питома активність ${ }^{137} \mathrm{Cs}$ у м'язах була у 60, 90, 120, 150-денному віці відповідно на 22,1; 40,3; 34,4 і 40,6 \% меншою у порівнянні із м'язами качок безвигульного способу утримання (2001р.).

У дослідженнях 2012 року питома активність ${ }^{137} \mathrm{Cs}$ у м'язах качок за вигульного способу утримання по періодах вирощування була меншою відповідно на 21,2; 41,5; 31,8 і $46,6 \%$.

У качок вигульного способу утримання накопичення ${ }^{137} \mathrm{Cs}$ відбувалося до 60-денного віку, а потім відбувався процес зниження концентрації радіонукліду.

Результатами досліджень встановлено, що концентрація радіонукліда у м'язах качок обох груп у 2012 році значно знизилася у порівнянні із показниками 2001 року.

Висновки. Зроблено теоретичне та практичне об- ґрунтування екологічної безпеки виробництва м'яса качки як одного з основних продуктів харчування населення, що проживає в регіонах, які зазнали радіоактивного забруднення внаслідок аварії на ЧАЕС.

У результаті проведених досліджень досліджено ріст і розвиток птиці, вивчено накопичення ${ }^{137} \mathrm{Cs}$ у м'язах качок за умов їх вирощування на місцевих кормах за вигульного i безвигульного способів утримання на території радіоактивного забруднення.

Результатами досліджень доведено, що на ріст та розвиток качок впливають способи їх утримання. За вигульного способу утримання жива маса качок була більшою у межах 2,5-4,9 \% порівняно із птицею безвигульного способу утримання. Качки вигульного способу утримання характеризувалися кращим розвитком внутрішніх органів, масою патраних тушок, виходом м'язів.

Дослідженнями встановлено, що питома активність ${ }^{137} \mathrm{Cs}$ у м'ясі піддослідних качок обох груп не перевищувала допустимі рівні. Вміст радіонукліду знаходився у межах 14,3-75,9 - у 2001 році та 12,9-60,0 Бк/кг - у дослідженнях 2012 року. Питома активність ${ }^{137} \mathrm{Cs}$ у м'язах качок вигульного способу утримання була на 21-46 \% меншою, відповідно по періодах, у порівнянні із птицею безвигульного способу утримання.

\section{Список використаної літератури:}

1. Ведення сільськогосподарського виробництва на територіях, забруднених внаслідок Чорнобильської катастрофи, у віддалений період. Методичні рекомендації; за заг. ред. акад. УААН Б. С. Прістера. К. : Атіка-Н, 2007. 196 с.

2. Гадиев Р. Р., Коноплева А. П. Приусадебное птицеводство. Уфра : Издательство БГАУ, 1997. С. 3-91.

3. Гудков І. М. Радіоекологія як наука: історія та сучасні проблеми. Київ : НУБіП України, 2011. 505 с.

4. Гудков І. М. Становлення сільськогосподарської радіоекології в Україні: етапи розвитку, досягнення, проблеми, перспективи. Агроекологічний журнал. 2017. Вип. № 2. С. 58-66.

5. Дутов О. І. Агроекологічні підходи до мінімізації доз опромінення населення у віддалений період розвитку радіологічної ситуації після аварії на ЧАЕС. Екологічні науки. 2014. Вип. № 5. С. 24-31.

6. Забулонов Ю. Л., Буртняк В. М., Одукалець Л. А. Система для радіаційного контролю продуктів харчування та будівельних матеріалів. Геохімія Техногенезу. 2016. Вип. 25. С. 17-25.

7. Ковальова С. П. Виробництво радіологічно безпечної продукції птахівництва на радіаційно забрудненій території. Агроекологічний журнал. 2016. Вип. № 1. С. 65-70.

8. Ковальова С. П. Екологічне обґрунтування вирощування качок на радіоактивно забруднених територіях Полісся України : авторес. дис. ... канд. с.-г. наук : 03.00.16. Житомирський нац. агроек. ун-т. Житомир, 2015. 20 с.

9. Ковальова С. П., Ільніцька О. В., Рубан І. М. Сучасний радіологічний стан сільськогосподарських угідь Житомирського Полісся. Подільський вісник: сільське господарство, техніка, економіка. 2017. Вип. 26(1). С. 72-79.

10. Концепція ведення агропромислового виробництва на забруднених територіях та їх комплексної реабілітації на період 2000-2010 рр. Київ: СВIT, 2000. 48 с.

11. Наслідки аварії на Чорнобильській АЕС [Електронний ресурс]. Режим доступу: http://ukrmap.su/ukg8/893.html (дата звернення: 22.02.2021).

12. Національна доповідь України «25 років Чорнобильської катастрофи. Безпека майбутнього». Київ : КІМ, 2011. $356 \mathrm{c}$.

13. Дутов О. І., Ландін В. П., Мельничук А. О., Гриник О. І. Радіаційно-екологічні аспекти використання забруднених земель у віддалений період після аварії на Чорнобильській АЕС. Агроекологічний журнал. 2015. Вип. № 1. С. 115-121.

14. Романчук Л. Д. Радіоекологічна оцінка фрормування дозового навантаження у мешканців сільських територій Полісся України : монографрія. Житомир : Полісся, 2015. 300 с.

15. Романчук Л. Д., Лопатюк О. В., Ковальова С. П. Оцінка вмісту радіонукліду ${ }^{137} \mathrm{Cs}$ у продуктах харчування мешканців радіоактивно забруднених територій у віддалений період після аварії на ЧАЕС. Наукові горизонти. 2019. Вип. № 8 (81). C. 82-86. DOI: 10.33249/2663-2144-2019-81-8-82-86.

16. Савчук І. М., Савченко Ю. І., Савченко М. Г. Виробництво тваринницької продукції в зоні техногенного навантаження. Житомир : Рута, 2014. 372 с.

17. Сільськогосподарська водоплавна птиця в Україні [Електронний ресурс]. Режим доступу: https://a7d.com.ua/agropoltika/agri-work/5547-slskogospodarska-vodoplavna-pticya-v-ukrayin.html (дата звернення: 17.03.2021).

18. Соціально-економічний розвиток територій, що постраждали внаслідок аварії на Чорнобильській АЕС: проблеми та шляхи їх подолання: матеріали «круглого столу» ; за заг. ред. д. політ. наук О. В. Литвиненка. Київ: НІСД, 2011. 72 с. 
19. Фурдичко О. І., Кучма М. Д., Паньковська Г. П. Пріоритетні напрями наукового забезпечення сільськогосподарського виробництва на радіоактивно забруднених територіях. Агроекологічний журнал. 2011. Вип. № 1. С. 21-26.

20. Alexakhin, R. M. Radioecology: History and stateof-the-art at the beginning of the 21th century. Radiation Risk Estimates in Normal and Emergency Situations. Springer, 2006. P. 159-168. DOI: https://doi.org/10.1134/S1019331610020085.

21. Behaviour of radionuclides in natural and semi-natural environments (Ed. M. Belli and F. Tikhomirov). Experimental collaboration project № 5. Final report. CSC-EC-EAEC. Brussels and Luxembourg, 1996. 147 p.

22. Hinton T. G, Alexakhin R., Balonov M., Gentner N., Hendry J., Prister B., Strand P, Woodhead D. Health Phys. Radiation-induced effects on plants and animals: findings of the United Nations Chernobyl Forum. 2007. Nov; 93(5):427-40. DOI: 10.1097/01.HP.0000281179.03443.2e.

23. Prister B. S., Perepelyatnikov G. P., Perepelyatnikova L. V. Countermeasures used in the Ukraine to produce forage and animal food products with radionuclide levels below intervention limits after Chernobyl accident. The Science of Total Environment. 1993. № 137. Pp. 183-198.

24. Simonoff M., Sergeant C., Poulain S., Pravikoff M. S. Microorganisms and migration of radionuclides in environment. Comptes Rendus Chim. 2007. № 10, Pp. 1092-1107. DOI: http://dx.doi.org/10.1016/j.crci.2007.02.010.

\section{References:}

1. Vedennia silskohospodarskoho vyrobnytstva na terytoriiakh, zabrudnenykh vnaslidok Chornobylskoi katastrofy, u viddalenyi period. Metodychni rekomendatsii [Conducting agricultural production in areas contaminated by the Chernobyl disaster in the remote period. Guidelines]. 2007. Za zah. red. akad. YAAN B. S. Pristera. Kyiv : Atika-N. 196.

2. Hadyev, P. P., Konopleva, A. P., 1997. Pryusadebnoe ptytsevodstvo [Home poultry farming]. Ufa : Yzdatelstvo BHAU. pp. 3-91.

3. Hudkov, I. M., 2011. Radioekolohiia yak nauka: istoriia ta suchasni problemy [Radioecology as a science: history and modern problems]. Kyiv : NUBiP Ukrainy. 505 p.

4. Hudkov, I. M., 2017. Stanovlennia silskohospodarskoi radioekolohii v Ukraini: etapy rozvytku, dosiahnennia, problemy, perspektyvy [Formation of agricultural radioecology in Ukraine: stages of development, achievements, problems, prospects]. Ahroekolohichnyi zhurnal [Agroecological journal], issue 2, pp. 58-66.

5. Dutov, O. I., 2014. Ahroekolohichni pidkhody do minimizatsii doz oprominennia naselennia u viddalenyi period rozvytku radiolohichnoi sytuatsii pislia avarii na ChAES [Agroecological approaches to minimize radiation doses in remote periods of development of the radiological situation after the accident]. Ekolohichni nauky [Environmental Sciences], issue 5, pp. 24-31.

6. Zabulonov, Yu. L., Burtniak, V. M., Odukalets, L. A., 2016. Systema dlia radiatsiinoho kontroliu produktiv kharchuvannia ta budivelnykh materialiv [The System for Radiation Control of Foodstuffs and building Materials]. Heokhimiia Tekhnohenezu [Geochemistry of Technogenesis], issue 25, pp. 17-25.

7. Kovalova, S. P., 2016. Vyrobnytstvo radiolohichno bezpechnoi produktsii ptakhivnytstva na radiatsiino zabrudnenii terytorii [Production of radiologically safe poultry products in radiation-contaminated territory]. Ahroekolohichnyi zhurnal [Agroecological journal], issue 1, pp. 65-70.

8. Kovalova, S. P., 2015. Ekolohichne obgruntuvannia vyroshchuvannia kachok na radioaktyvno zabrudnenykh terytoriiakh Polissia Ukrainy [The Ecological Substantiation of raising ducks on radiocontaminated territories of Ukrainian Polissia]. Abstract of Ph.D dissertation. Zhytomyrskyi nats. ahroek. un-t. Zhytomyr.

9. Kovalova, S.P., Ilnitska, O. V., Ruban, I. M., 2017. Suchasnyi radiolohichnyi stan silskohospodarskykh uhid Zhytomyrskoho Polissia [Actual Condition of Radioactively Polluted Agricultural Lands of Polissia Zone, Zhytomyr Region]. Podilskyi visnyk: silske hospodarstvo, tekhnika, ekonomika [Podilian Bulletin: agriculture, engineering, economics], issue 26(1), Pp. 72-79.

10. Kontseptsiia vedennia ahropromyslovoho vyrobnytstva na zabrudnenykh terytoriiakh ta yikh kompleksnoi reabilitatsii na period 2000-2010 rr. [The concept of conducting agro-industrial production in contaminated areas and their comprehensive rehabilitation for the period 2000-2010]. Kyiv: SVIT, 2000. 48 p.

11. Naslidky avarii na Chornobylskii AES [Consequences of the Chernobyl accident] [Elektronnyi resurs]. Available at: http://ukrmap.su/ukg8/893.html (Accessed 22 February 2021).

12. Natsionalna dopovid Ukrainy "25 rokiv Chornobylskoi katastrofy. Bezpeka maibutnoho» [National Report of Ukraine "25 years of the Chernobyl disaster. Security of the future "]. Kyiv: KIM, 2011. 395 p.

13. Dutov, O. I., Landin, V.P., Melnychuk, A. O., Hrynyk, O. I., 2015. Radiatsiino-ekolohichni aspekty vykorystannia zabrudnenykh zemel u viddalenyi period pislia avarii na Chornobylskii AES [Radiation and environmental aspects of the use of contaminated land in the remote period after the Chernobyl accident]. Ahroekolohichnyi zhurnal [Agroecological journal], issue 1. pp. 115-121.

14. Romanchuk, L. D., 2015. Radioekolohichna otsinka formuvannia dozovoho navantazhennia u meshkantsiv silskykh terytorii Polissia Ukrainy [Radioecological assessment of dose loading in residents of rural areas of Polissya, Ukraine] : monohrafiia. Zhytomyr : Polissia. 300 p.

15. Romanchuk, L. D., Lopatiuk, O. V., Kovalova, S.P., 2019. Otsinka vmistu radionuklidu ${ }^{137}$ Cs u produktakh kharchuvannia meshkantsiv radioaktyvno zabrudnenykh terytorii u viddalenyi period pislia avarii na ChAES [Evaluation of the content of ${ }^{137} \mathrm{Cs}$ radionuclide in food products of residents of radio actively contaminated territories in The Long-Term Period after the Chernobyl Accident]. Naukovi horyzonty [Scientific Horizons], issue 8 (81), pp. 82-86. DOI: 10.33249/2663-2144-2019-81-8-82-86.

16. Savchuk, I. M., Savchenko, Yu. I., Savchenko, M. H., 2014. Vyrobnytstvo tvarynnytskoi produktsii $v$ zoni tekhnohennoho navantazhennia [Livestock production in the man-made loading zone]. Zhytomyr : Ruta, $372 \mathrm{p}$. 
17. Silskohospodarska vodoplavna ptytsia v Ukraini [Agricultural Waterfowl in Ukraine] [Elektronnyi resurs]. Available at: https://a7d.com.ua/agropoltika/agri-work/5547-slskogospodarska-vodoplavna-pticya-v-ukrayin.html (Accessed 17 March 2021).

18. Sotsialno-ekonomichnyi rozvytok terytorii, shcho postrazhdaly vnaslidok avarii na Chornobylskii AES: problemy ta shliakhy yikh podolannia: materialy "kruhloho stolu» [Socio-economic development of the territories affected by the Chernobyl accident: problems and ways to overcome them: materials of the round table]; za zah. red. O.V.Lytvynenka. Kyiv: NISD, 2011.72 s.

19. Furdychko, O.I., Kuchma, M. D., Pankovska, H.P., 2011. Priorytetni napriamy naukovoho zabezpechennia silskohospodarskoho vyrobnytstva na radioaktyvno zabrudnenykh terytoriiakh [Priority areas of scientific support of agricultural production in radioactively contaminated areas]. Ahroekolohichnyi zhurnal [Agroecological journal], issue 1, pp. 21-26.

20. Alexakhin, R. M., 2006. Radioecology: History and stateof-the-art at the beginning of the 21th century. Radiation Risk Estimates in Normal and Emergency Situations. Springer. P. 159-168. DOI: https://doi.org/10.1134/S1019331610020085.

21. Behaviour of radionuclides in natural and semi-natural environments (Ed. M. Belli and F. Tikhomirov). Experimental collaboration project № 5. Final report. CSC-EC-EAEC. Brussels and Luxembourg, 1996. 147 p.

22. Hinton T. G, Alexakhin R., Balonov M., Gentner N., Hendry J., Prister B., Strand P, Woodhead D., 2007. Health Phys. Radiation-induced effects on plants and animals: findings of the United Nations Chernobyl Forum.. Nov; 93(5):427-40. DOI: 10.1097/01.HP.0000281179.03443.2e.

23. Prister B. S., Perepelyatnikov G. P., Perepelyatnikova L. V., 1993. Countermeasures used in the Ukraine to produce forage and animal food products with radionuclide levels below intervention limits after Chernobyl accident. The Science of Total Environment, issue137, pp. 183-198.

24. Simonoff M., Sergeant C., Poulain S., Pravikoff M. S., 2007. Microorganisms and migration of radionuclides in environment. Comptes Rendus Chim, issue 10, pp. 1092-1107. DOI: http://dx.doi.org/10.1016/j.crci.2007.02.010.

Kovalova Svitlana Petrivna, The Head of the Laboratory of Soils Ecological Safety, Environment and Production Quality, Zhytomyr branch of State Institution «Institute of Soil Protection of Ukraine»

Ilnitska Olena Volodymyrivna, The Head of the Laboratory of Experimental Researches, Geoinformatic Systems and Data Processing, Zhytomyr branch of State Institution «Institute of Soil Protection of Ukraine»

Havrylovskyi Volodymyr Petrovych, Lecturer, Vice-principal for Education and Production, Zhytomyr Agrotechnical College

Verbelchuk Serhii Petrovych, Candidate of Agricultural Sciences, Associate Professor, Polissia National University (Zhytomyr, Ukraine) Ukraine)

Koberniuk Vira Vasylivna, Candidate of Agricultural Sciences, Associate Professor, Polissia National University (Zhytomyr,

Verbelchuk Tetiana Vasylivna, Candidate of Agricultural Sciences, Associate Professor, Polissia National University (Zhytomyr, Ukraine)

\section{contamination}

Comparative characteristics of meat and slaughter qualities of ducks during raising in the area of radioactive

The article presents the results of research on meat and slaughter qualities of ducks under different methods of keeping during raising in subsidiary farms of the 2 nd zone of radioactive contamination. The ecological safety of duck meat production with indoor and outdoor breeding is theoretically and practically substantiated as the main source of protein in the diet of the population living in the regions affected by radioactive contamination as a result of the Chernobyl accident. Scientific and economic research on the raising of ducks in radioactively contaminated areas was conducted in 2011-2012 in the village of Khrystynivka, Narodychi district, Zhytomyr region. The density of cesium contamination -137 was $>15$ curies per square kilometer. For experiments on the principle of pairs of analogues were selected 60 heads of ducks with an average live weight of $40.6 \mathrm{~g}$. each one (in confinement), from the age of 30 days ducks were divided into two groups depending on the method of breeding - outdoor and indoor, 25 heads in each, the average live weight of ducklings was $520 \mathrm{~g}$. The experimental duck of indoor breeding was kept in a fence during the day, which, thanks to the canopy, protected it from adverse weather conditions, and the ducks spent the nights indoors. Experimental ducks (outdoor breeding) were with a natural restriction on the territory of the reservoir 0,4-0,6 he during the day. Ducks were fed in cages and spent the nights in closed premises. Ducks were provided with nutrients through balanced feeding rations, as limited water bodies were poor in natural forage. Research shows that duck breeding methods have a significant effect on the growth and development of poultry, the weight of gutted carcasses, the yield of carcass components, and the accumulation of ${ }^{137} \mathrm{Cs}$ in poultry meat. The ducks of outdoor breeding were characterized by higher live weight, better development of internal organs, the weight of gutted carcasses, muscle output. Studies have shown that the specific activity of ${ }^{137} \mathrm{Cs}$ in the meat of experimental ducks of both groups did not exceed the permissible levels and ranged from 12,9 to $75,9 \mathrm{~Bq} / \mathrm{Kg}$. The specific activity of ${ }^{137} \mathrm{Cs}$ in the muscles of outdoor breeding ducks was 21-46\% lower than that of indoor breeding. The ecological safety of duck meat production for the inhabitants of the 2 nd zone of radioactive contamination, both of the indoor and outdoor breeding, is substantiated, giving preference to the latter.

Key words: ducks, indoor and outdoor breeding, radioactively contaminated territory, specific activity, growth and development, gutted carcass, finish weight.

Дата надходження до редакції: 22.03.2021 p. 